\title{
Exploration on the Teaching Reform of Ideological and Political Theory Course under the Visual Field of "Internet+"
}

\author{
Huihua Zhang ${ }^{1, \text { a }}$, Qilin Qiu ${ }^{2, b}$ and Yongfeng $\mathrm{Hu}^{1, \mathrm{c}}$ \\ ${ }^{1}$ College of Science and Art, Jingdezhen Ceramic University, Jingdezhen, 333000 \\ ${ }^{2}$ Jingdezhen Ceramic University, Jingdezhen, 333000 \\ a253313652@qq.com, b277483040@qq.com, ${ }^{\mathrm{c}}$ 1286313671@qq.com
}

\begin{abstract}
Keyword: "Internet +"; Teaching Reform; Ideological and Political Theory Course
\end{abstract}
\begin{abstract}
This paper takes the course of "Introduction to Maoism and Chinese-featured Socialism Ideology Applied Technology of Database" as an example, to analyze the necessity of the teaching reform in the ideological and political theory course under the visual field of "Internet $+"$, and to analyze the difficulties and problems in the teaching reform. Try to find the appropriate path to reform.
\end{abstract}

\section{Introduction}

Report on the work of the government in 2015, Premier Li Keqiang posed an action plan, that is "Internet + " be formulated. Carrying out the research work of combining "Internet + " with ideological and political theory courses has a positive promotion significance for the innovation and the promotion of ideological and political education in colleges and universities.

\section{Necessity of Teaching Reform of Ideological and Political Theory Course}

Teaching Content Must Keep Up with the New Era. According to the content of the course, the curriculum system and the content of the ideological and political course of China should keep pace with the times and keep pace with the new era. Take "Introduction to Maoism and Chinese-featured Socialism Ideology Applied Technology of Database" (hereinafter referred to as "Mao Zhonggai") published by the Higher Education Press as an example, this textbook has been revised many times. Each revision of the textbook brings the content constantly updated and perfected, the teacher only timely attention to current affairs, follow the hot times, in order to impart to students new knowledge and content, the only way to enrich the ideological and political classroom atmosphere and increase students' recognition of the course.[1]

Teaching Methods Must Be Responsive to the Needs of the Times. The updating of teaching content necessarily requires that the teaching method must keep up with the pace of the times. Under the "Internet +" era, the "two micro one end" new media represented by WeChat is rapidly popularizing and taking root in colleges and universities. Because of their flexibility, convenience and uniqueness, students prefer to obtain a large amount of information from the media, therefore the pictures and videos used by teachers may already be well known to students, and their attractiveness to students will be greatly discounted. In addition, in many colleges and universities, the ideological and political courses generally adopt the mode of taking classes in large classes. The ideological and political classrooms are crowded with people. The interaction effect with respect to small classes is not obvious. However, the "Internet + " mode of ideological and political theory of class interaction can break the time, space and number of people, and even geographical restrictions.

Teaching Evaluation Must Be Scientific and Reasonable. Judging from the current teaching evaluation of Ideological and political theory course in China, the majority of the courses are set up as inspection course, while a small number of schools arrange for examination courses, but most of them are open book examination. Therefore, the curriculum set to some extent affected the enthusiasm and initiative of students to learn, but also to a certain extent, reduce the students' 
emphasis on the curriculum. In this regard, our teachers can try on their usual performance, a comprehensive evaluation by using information technology, such as increasing the practical evaluation, make teaching evaluation more comprehensive and accurate

\section{Analysis of Teaching Reform of Ideological and Political Theory Course}

Relative Lack of Teaching Input, Teaching Methods Are too Single. On the one hand, the lack of investment in Ideological and political theory courses both on the office conditions and equipment is relatively inadequate, and the theoretical class hours, practice is not enough. On the other hand, the teaching methods and means of Ideological and political education are single and need to be diversified. "Teachers say, students listen," this kind of inculcating teaching, it is difficult to achieve the effect of an active classroom atmosphere. This requires the teachers in the process of peacetime are good at using the network to learn, well-designed teaching, when the students' attention is not concentrated or decline, and constantly increase teacher-student interaction [2]. At present, many teachers begin to adopt heuristic guidance, case teaching, feedback teaching and flipped classroom. But how to make rational use of the Internet, such as WeChat public platform, real-time network class and other multimedia means of teaching, need further exploration.

Students Lack the Initiative to Learn, Enthusiasm Is Obviously not Enough. At present, most university students pay more attention to professional learning than ideological and political education. Even some students think that ideological and political education can learn without learning and there is absolutely no enthusiasm and enthusiasm for learning. The deviation of college students from the subjective understanding of the ideological and political courses is not obvious for the purpose of learning these courses and has limited application in the future major. Therefore, the learning in the classroom is relatively passive and the awareness of interaction is not enough. On the other hand, at present, the practice teaching of ideological and political education is often in the form of practical teaching. Simply writing an essay or reading a book does not really allow students to take part in practical exercises.

The Assessment Method of Ideological and Political Theory Course is Relatively Simple and Lacks Extensive Evaluation. At present, the assessment methods of ideological and political course in colleges and universities are too simple, and they are mainly evaluated by way of examining scores. At present, the evaluation methods of Ideological and political course in Colleges and universities are too single, and the evaluation methods are basically used to evaluate the results. Mainly from the end of each semester course give students' scores, lack of usual test assessment, extracurricular practice activities less or practice too formal. This kind of assessment method cannot timely test students' mastery of relevant theoretical knowledge, but also cannot fully investigate the learning effect of students. Taking "MaoZhonggai" as an example, the assessment of this course is mainly based on the assessment of the final papers. The examination methods often only detect the mastery of class students to a part of theoretical knowledge, but cannot measure whether the overall theoretical level of students is improved or not. Of course, when reforming the teaching evaluation, how to formulate the assessment method in a comprehensive, fair and effective manner and apply it is a big challenge, as is the case of politics and politics.

\section{The Exploration of Teaching Reform in Ideological and Political Theory Course}

University Administrators Should Further Enhance Their Understanding of the Ideological and Political Theory Course. The course of ideological and political theory is an important way for contemporary college students to systematically study Marxist theory and also the main way to accept ideological and political education. colleges and universities should continue to innovate on the system, step up their efforts at the management level, and promote the overall level of the study of the course of ideological and political theory with the thinking of "Internet $+"$. At the school level, ideological and political theory courses should be set up to increase teaching time, to multi-organizational teachers to participate in all levels of various types of training and learning, to increase the input of teaching and research. 


\section{Teachers Should Update Their Teaching Concepts and Constantly Improve Their Teaching} Results. In the actual teaching, teachers of ideological and political courses in colleges and universities should constantly improve their own teaching and information literacy, use network resources scientifically and reasonably, and give full play to the rapid transmission of information in the era of "Internet +". In "Mao zhonggai", when teach the contents of "rule of law in accordance with the law, building a socialist country ruled by law", we can choose 2017 anti-corruption documentary "forever on the road," the documentary panoramic view of the "Strict adhere to the party forever on the road" four The extraordinary course of the past year has allowed students to genuinely accept the idea of equality before the law and benefit students for life after seeing them. In the process of teaching ideological and political education, teachers must pay attention to the humane care of students, increasing themselves personal charisma, give efforts to become welcomed teachers, so as to achieve better teaching results.

Update the Teaching Concept, Establish the Concept of Online and Offline Integration. Both teachers and students should set up innovative ideas. The ideological and political classrooms need to build "Internet + learning", "Internet + classroom", "Internet + S \& T" and other online platforms promote the Internet and the ideological and political comprehensive and in-depth integration of the classroom. Then hold the "online" main front. We will give full play to the advantages of dissemination of online micro-media, such as "Two micro ends," so as to promote the synchronization of ideological and political classrooms with the times, resonate with teachers, and work with students to enhance the attractiveness of the ideological and political classrooms. Because of the use of online platform is to improve the effectiveness of the ideological and political education. On the one hand, the online platform can be deeply embedded in the teaching process of the classroom, increase the interest of the ideological and political classroom, and also can build independent online virtual classrooms. For example, the most popular in major universities is "MOOC class".

Taking Students as the Leading Factor and Setting Up the Idea of Precise Supply. The report of the 19th National Congress of CPC pointed out: "After long-term efforts, socialism with Chinese characteristics has entered a new era. This is a new historical position for our country's development". We must grasp the characteristics of the "new era"; master the ideological and political classes in the leading position, leading the latest Marxist theory of the main theme of the class. At the same time, grasp the principle of teaching theory, content matching, information selection accuracy, in-depth analysis of textbooks use to promote learning more accurate and refined. Another is to grasp the effect of classroom teaching, enhance effectiveness and accuracy.

Refinements of Curriculum, Assessment Indicators, Improve the Curriculum Evaluation System. Teacher evaluation is an important means to improve teaching methods, as well as an effective way for teachers to perfect teaching methods. At present, the evaluation of curriculum, teaching in ideological and political course is based mainly on essay writing or open book examinations, which makes it difficult to evaluate student learning effectively. It is necessary to formulate the evaluation index system with the characteristics of ideological and political education. For instance, when evaluating the students in the course of "Mao Zhonggai", the theory and practice are respectively examined, and the individual evaluation is conducted through the progress of the theory and practice. In the assessment index range, such as the class lectures seriousness, the degree of classroom interaction, the richness of theoretical knowledge, extracurricular practical ability included in the assessment of the curriculum from a single model in multiple models, increase students' enthusiasm for classroom and extra-curricular learning.

\section{Conclusion}

The rapid development of the Internet has extended the connotation of ideological and political theory, increased the content of college classrooms, and changed the way of teaching and learning of ideological and political courses. When the ideological and political classrooms, enter a new stage of "Internet $+"$ mode, opportunities and challenges coexist, which requires teachers to make updates and version upgrades to the ideological and political courses under the "Internet +". So as to 
make the ideological and political classrooms more scientific, rational and effective, and to enable contemporary college students' experience in "Internet + Classrooms" more fun, the real work of ideological and political education to a higher level.

\section{Acknowledgement}

FundProject.2017 annual humanities and social science research projects in universities in Jiangxi Province: "Internet $+"$ under the field of ideological and political education in colleges and universities work online and offline innovation (MKS17208); 2016 Jiangxi Provincial Party Building Project: Research on the Innovation of the basic-level party construction work in colleges under the visual field of "Internet+" (16DJQN034)

\section{References}

[1] J.Su.On the current ideological and political reform in colleges and universities should emphasize the "four combinations". Human Resource Management. 2017 (10)

[2] J. b. Lei, Y. Guo "Micro-era" to enhance the effectiveness of the ideological and political course of colleges and universities to explore the path. Vocational Education Forum.2016 (20) 